\title{
Reversal of $\beta$-Cell Suppression In Vitro in Pancreatic Islets Isolated from Nonobese Diabetic Mice during the Phase Preceding Insulin-dependent Diabetes Mellitus
}

\author{
Eva Strandell, Décio L. Eizirik, and Stellan Sandler \\ Department of Medical Cell Biology, Uppsala University, S-751 23 Uppsala, Sweden
}

\begin{abstract}
Insulin-dependent diabetes mellitus (IDDM) is characterized by a progressive autoimmune destruction of the pancreatic $\beta$ cells. One of the best-suited animal models for IDDM is the nonobese diabetic (NOD) mouse. In this investigation pancreatic islets were isolated from female NOD mice aged 5-7, 8-11, and 12-13 wk and examined immediately (day 0) or after $7 \mathrm{~d}$ of culture (day 7). The mice showed a progressive disturbance in glucose tolerance with age, and a correspondingly increased frequency of pancreatic insulitis. Islets isolated from the oldest mice often contained inflammatory cells on day $\mathbf{0}$, which resulted in an elevated islet DNA content. During culture these islets became depleted of infiltrating cells and the DNA content of the islets decreased on day 7. Islets of the eldest mice failed to respond with insulin secretion to high glucose, whereas a response was observed in the other groups. After culture all groups of islets showed a markedly improved insulin secretion. Islets from the 12-13-wk-old mice displayed a lower glucose oxidation rate at $16.7 \mathrm{mM}$ glucose on day 0 compared with day 7 . Islet (pro)insulin and total protein biosynthesis was essentially unaffected. In conclusion, islets obtained from 12-13-wk-old NOD mice exhibit an impaired glucose metabolism, which may explain the suppressed insulin secretion observed immediately after isolation. This inhibition of $\beta$-cell function can be reversed in vitro. Thus, there may be a stage during development of IDDM when $\beta$-cell destruction can be counteracted and $\beta$-cell function restored, provided the immune aggression is arrested. (J. Clin. Invest. 1990. 85:1944-1950.) diabetes mellitus $\bullet$ insulin release $\bullet$ nonobese diabetic mouse $\bullet$ pancreatic islets
\end{abstract}

\section{Introduction}

Insulin-dependent diabetes mellitus (IDDM) ${ }^{1}$ is characterized by a progressive autoimmune destruction of the insulin-producing $\beta$-cells of the pancreas (1). At present one of the bestsuited animal models for the study of IDDM is the nonobese

Address reprint requests to Dr. Strandell, Department of Medical Cell Biology, Biomedicum, P.O. Box 571, S-751 23 Uppsala, Sweden.

Received for publication 7 November 1989 and in revised form 10 December 1990.

1. Abbreviations used in this paper: IDDM, insulin-dependent diabetes mellitus; KRBH, Krebs-Ringer bicarbonate Hepes buffer; NOD, nonobese diabetic (mice).

J. Clin. Invest.

(c) The American Society for Clinical Investigation, Inc.

0021-9738/90/06/1944/07 $\$ 2.00$

Volume 85, June 1990, 1944-1950 diabetic (NOD) mouse. Since its discovery the NOD mouse has been extensively investigated (2-4), especially regarding the type of cells infiltrating the pancreatic islets $(5,6)$, genes conveying suceptibility for the disease (7-9), and different attempts to prevent the outbreak of diabetes (10-13). An additional crucial issue in understanding the course of the disease is to elucidate the damaging mechanism(s) inflicted by the immune cells to the $\beta$-cells. In this context it is also of importance to find out whether the $\beta$-cells during ongoing autoimmune assault are able to pass through a phase of cell repair and resume a normal function. Such studies have up to now been hampered by the problems of isolating islets from animals with insulitis, i.e., immune cell infiltration of the islets.

In the present study we have succeded in isolating islets from NOD mice up to 13 wk of age and with an increasing degree of insulitis. Pancreatic $\beta$-cell function was studied both immediately after islet isolation and after $1 \mathrm{wk}$ of tissue culture. The results show that there is a progressive deterioration with age of the islet capacity to release insulin in response to glucose stimulation, but that the cells are able to recover their function after culture.

\section{Methods}

The local NOD mouse strain. The NOD mouse colony was established in Uppsala in March 1988 in the Animal Department of the Biomedical Centre (Uppsala, Sweden) by brother and sister mating from three breeding pairs of inbred NOD mice obtained from the Clea Company, Aobadi, Japan. The cumulative diabetes incidence in the NOD mouse colony by $28 \mathrm{wk}$ of age is $47 \%$ in the female and 7\% in the male mice. Diabetes mellitus was verified by positivity for glucosuria (Clinistix, Bayer AB, Göteborg, Sweden) and a serum glucose concentration $>14 \mathrm{mM}$.

Intravenous glucose tolerance test. Normoglycemic nonstarved NOD females from three different age groups (5-7, 8-11, and 12-13 wk) were studied. The mice were injected in a tail vein with $2.5 \mathrm{~g} / \mathrm{kg}$ body weight of a $30 \%$ glucose solution. Blood samples were obtained by retroorbital sinus puncture at time points $0,15,60$, and $120 \mathrm{~min}$. The serum glucose concentration was analyzed using an automated glucose oxidase method (Glucose Analyzer 2, Beckman Instruments, Inc., Fullerton, CA). On the following day the animals were killed and their pancreatic islets used for in vitro experiments (see below).

Islet morphology. From each female mouse studied in the insulin release experiments (see below), a piece of the pancreas was fixed in Bouin's solution for light microscopical examination. At least 60 consecutive sections, $7 \mu \mathrm{m}$ thick, were cut and stained with hematoxylin and eosin. The presence of inflammatory cells in the islets was ranked according to four arbitrary classes as previously defined and illustrated $(14,15)$. Class A denotes normal islet morphology; class B denotes a low degree of mononuclear cell infiltration especially in the periinsular area; class $C$ denotes a heavy cell infiltration into a majority of islets, i.e., insulitis; and class $D$ denotes only a few residual islets remaining exhibiting an altered islet architecture with cells often containing pyknotic nuclei or showing other signs of degeneration.

Islet isolation and culture. Pancreatic islets were isolated by a col- 
lagenase digestion procedure (16) from nonstarved female NOD mice and from nonstarved outbred 12-wk-old male NMRI mice (Anticimex $\mathrm{AB}$, Sollentuna, Sweden), the latter being a non-diabetes-prone strain of mice without any known autoimmune disease which has been extensively studied in our laboratory as regards islet metabolism and function. From the NOD females islets were isolated according to the age groups described above. After 13 wk of age islet isolation from the mice was not feasible owing to severe inflammatory lesions of the islets.

The islets were either immediately used for experiments (day 0 ) or cultured free-floating in tissue culture medium RPMI 1640 (11.1 mM glucose) (Flow Laboratories, Irvine, Scotland) supplemented with $10 \%$ donor calf serum (Flow Laboratories), benzylpenicillin $(100 \mathrm{U} / \mathrm{ml})$, and streptomycin $(0.1 \mathrm{mg} / \mathrm{ml})$ at $37^{\circ} \mathrm{C}$ in air $+5 \% \mathrm{CO}_{2}$ for $7 \mathrm{~d}$, before further experiments were performed (day 7). The culture medium was exchanged every second day. The number of islets possible to isolate on day 0 and the number of islets remaining in culture on day 7 was calculated for each individual NOD mouse.

Measurements of islet insulin release and islet insulin and DNA contents. To determine islet insulin release, triplicate groups of seven islets were placed in sealed glass vials (17) containing $0.25 \mathrm{ml}$ of a bicarbonate buffer (18) supplemented with $10 \mathrm{mM}$ Hepes (Sigma Chemical Co., St. Louis, MO) hereafter referred to as Krebs-Ringer bicarbonate Hepes buffer (KRBH), containing $2 \mathrm{mg} / \mathrm{ml}$ bovine serum albumin (BSA) (Miles Laboratories, Slough, UK). During the first 60 min of incubation at $37^{\circ} \mathrm{C}\left(\mathrm{O}_{2} / \mathrm{CO}_{2} ; 95: 5\right)$ the $\mathrm{KRBH}$ contained 1.7 $\mathrm{mM}$ glucose. The medium was then gently removed and replaced by $0.25 \mathrm{ml} \mathrm{KRBH}$ supplemented with $16.7 \mathrm{mM}$ glucose or $16.7 \mathrm{mM}$ glucose $+5 \mathrm{mM}$ theophylline and the islets were incubated for another $60 \mathrm{~min}$. Insulin secreted to the incubation media was measured by RIA (19). An anti-bovine insulin serum raised in guinea pigs (Miles-Yeda, Rehovot, Israel) was used as the primary serum, mouse crystalline insulin as standard (Novo Co., Copenhagen, Denmark) and ${ }^{125} \mathrm{I}-\mathrm{la}-$ beled insulin as a tracer (Novo Co.).

After the incubations the islets were collected and ultrasonically disrupted in $0.2 \mathrm{ml}$ of redestilled water, a fraction of the aqueous homogenate was mixed with acid-ethanol $(0.18 \mathrm{M} \mathrm{HCl}$ in $96 \%$ [vol/ vol] ethanol) and the insulin was extracted overnight at $4^{\circ} \mathrm{C}$. The insulin content of the extract was subsequently measured by the RIA. DNA was measured in another fraction of the water homogenate, according to the method of Kissane and Robins (20) as modified by Hinegardner (21).

Islet (pro)insulin and total protein biosynthesis. To determine (pro)insulin and total protein biosynthesis, groups of 20 islets were incubated at $37^{\circ} \mathrm{C}$ in $100 \mu \mathrm{l} \mathrm{KRBH}$ containing $2 \mathrm{mg} / \mathrm{ml} \mathrm{BSA}, 1.7$ or $16.7 \mathrm{mM}$ glucose, and $50 \mu \mathrm{Ci} / \mathrm{ml} \mathrm{L}-\left[4.5-{ }^{3} \mathrm{H}\right]$ leucine (Amersham International, Amersham, UK) in an atmosphere of humidified air $+5 \%$ $\mathrm{CO}_{2}$. After $2 \mathrm{~h}$, the islets were washed in Hanks' solution containing 10 $\mathrm{mM}$ nonradioactive leucine and then sonicated in $200 \mu \mathrm{l}$ of redestilled water. The amount of labeled (pro)insulin was determined by an immunoabsorption technique (22) and the total protein biosynthesis was measured in TCA precipitates of the islet homogenate.

Islet glucose oxidation. Triplicate groups of 10 islets each were incubated for 90 min in glass vials containing KRBH without BSA but supplemented with $\mathrm{D}-\left[\mathrm{U}-{ }^{14} \mathrm{C}\right]$ glucose (Amersham International) and nonradioactive glucose to a final concentration of 1.7 or $16.7 \mathrm{mM}$ glucose. The islet glucose oxidation was measured as described in detail elsewhere (23).

Statistical analyses. Means \pm SEM were calculated and groups of data were compared by the paired or unpaired Student's $t$ test.

\section{Results}

Intravenous glucose tolerance test in NOD mice. The 8-11-wk aged mice showed a slightly lower serum glucose concentration, before glucose injection, compared to the younger mice (5-7 wk), whereas the oldest group was similar to the youngest ones (Fig. 1). After glucose injection, there was a slightly higher

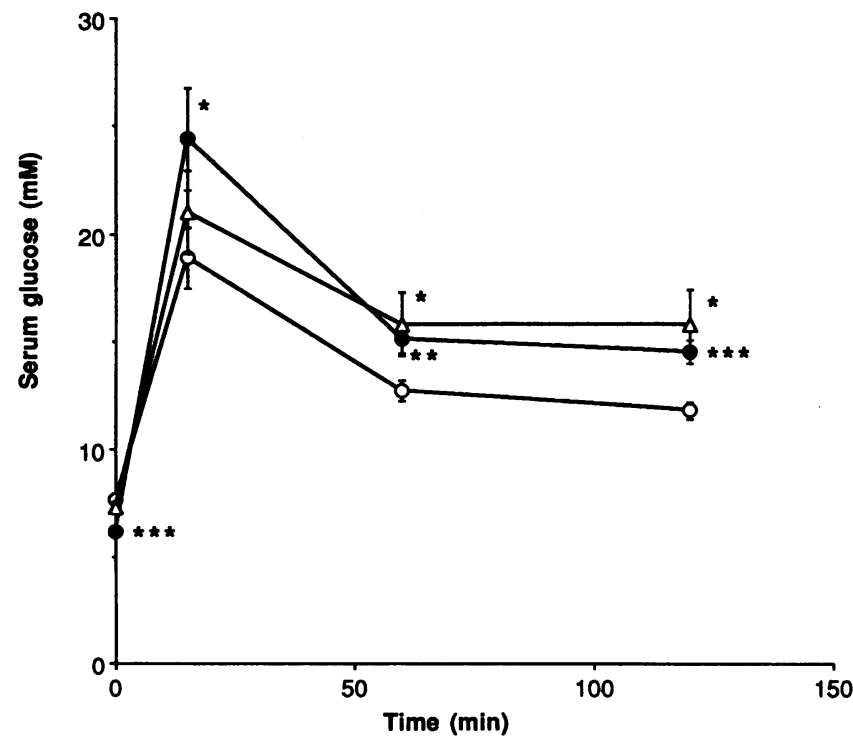

Figure 1. Intravenous glucose tolerance test in female NOD mice of different ages. The animals were given glucose $2.5 \mathrm{~g} / \mathrm{kg}$ body weight of a $30 \%$ glucose solution. Blood samples were obtained by retroorbital sinus puncture at time points $0,15,60$, and $120 \mathrm{~min}$. Values are means \pm SEM. ${ }^{*}$, ${ }^{* *}$, and ${ }^{* * *}$ denote $P<0.05,<0.01$, and $<0.001$, respectively, using Student's unpaired $t$ test, when comparing the 5-7-wk $(0 ; n=15)$ with the 8-11-wk $(0 ; n=13)$ and with the 12-13wk group $(\Delta ; n=14)$.

glycemic level after $15 \mathrm{~min}$ in the 8-11-wk-old mice, and at 60 and $120 \mathrm{~min}$ after the glucose load the serum glucose concentrations were elevated in the two oldest age groups compared with the youngest mice. It should be noted that the serum glucose concentration had not returned completely to the initial level in any of the groups after $120 \mathrm{~min}$.

Islet morphology. Examination of the pancreatic pieces excised from the different groups of mice revealed an increasing fraction of animals showing insulitis (class $\mathrm{C}$ ) in the older age groups (Table I). The 12-13-wk-old mice exhibited all a periinsular mononuclear cell infiltration (class B) or insulitis. The mononuclear cells were frequently gathered around the islets forming a capsulelike structure. This apparent capsule was also possible to detect on some islets immediately after isolation, especially in the oldest NOD mice (Fig. 2). After culture the islets became essentially devoid of the infiltrating cells (Fig. 3).

Islet DNA and insulin content and insulin release. The number of isolated islets obtained from the pancreas of the NOD mice was higher in the 5-7-wk-old group $(127 \pm 4 ; n$ $=16)$ than the 8-11-wk-old group $(84 \pm 7 ; n=15 ; P<0.001$; unpaired $t$ test) and the 12-13-wk-old group (79 $\pm 9 ; n=11 ; P$ $<0.001$ ). The percentage loss of islets during the 1 wk of culture was $\sim 15 \%$, in all groups (data not shown).

The DNA content on day 0 of the islets isolated from the two elderly groups of mice was elevated compared to the 5-7wk-old mice (Table II). However, the islet DNA content decreased on day 7 in the former two groups and became similar to the DNA content of the islets from the youngest mice. The DNA content of the islets obtained from the 5-7-wk-old mice did not change with culture. Also islets isolated from NMRI mice showed an unaffected DNA content (day 0, 213 \pm 20.2 ; day $7,166 \pm 12.4 \mathrm{ng}$ DNA/10 islets [ $n=9])$. 
Table I. Pancreatic Islet Histology in Female NOD Mice at Different Ages

\begin{tabular}{crrrrr}
\hline & \multicolumn{5}{c}{ Islet morphology rank } \\
\cline { 2 - 6 } Age & A & B & C & D \\
\hline$w k$ & & & $\%$ & & \\
$5-7$ & 42 & 58 & & 0 & 0 \\
$8-11$ & 8 & 33 & 59 & 0 \\
$12-13$ & 0 & 25 & 75 & 0 \\
& & & & & \\
\hline
\end{tabular}

The islet morphology of each animal was ranked according to four arbitrary classes: A, normal islet structure; B, mononuclear cell infiltration in the periinsular area; $C$, mononuclear cell infiltration in a majority of islets, i.e., insulitis; $D$, only a few residual islets exhibiting an altered islet architecture with cells often containing pyknotic nuclei or showing other signs of degeneration. 12 animals were scored in each age group.

The insulin content per islet was increased on day 0 in the 12-13-wk-old mice, but after the culture period it became significantly decreased compared with the 5-7-wk-old group (Table II). On the other hand, when the islet insulin content was expressed per DNA, it was decreased on day 0 in both the 8-11- and the 12-13-wk-old mice (Table II). This decrease persisted after culture of the islets isolated from the oldest mice, whereas this difference did not remain after culture of the islets isolated from 8-11-wk-old mice.

Islets incubated from NOD mice aged 5-7 or 8-11 wk responded on day 0 with an increased insulin release to 16.7 $\mathrm{mM}$ glucose when compared with the preceding incubation hour at $1.7 \mathrm{mM}$ glucose (Fig. 4). However, the islets obtained from the 12-13-wk-old mice failed to respond to high glucose. On day 0 there was also a progressive increase with age in the basal islet insulin secretion at $1.7 \mathrm{mM}$ glucose. After culture for $7 \mathrm{~d}$, the basal insulin release declined to similar levels in all groups of islets. Furthermore, the glucose-stimulated insulin secretion became much enhanced, as compared with day 0 , in all three groups $(P<0.001)$. Thus, the islets obtained from the

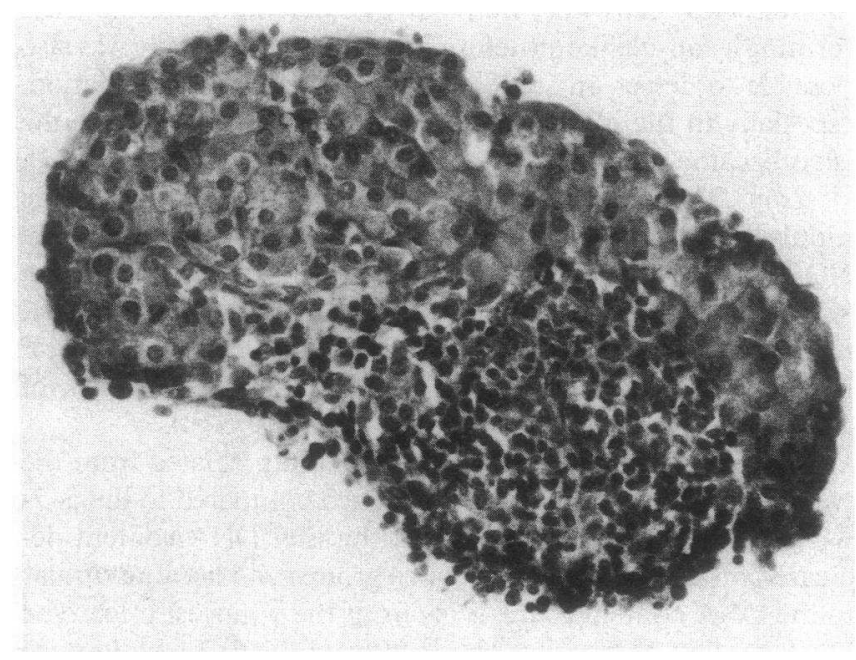

Figure 2. Light micrograph of a female NOD mouse islet, 12 wk of age, immediately after isolation (day 0 ). Mononuclear cell infiltration is seen in the islet. Hematoxylin and eosin. $\times 400$.

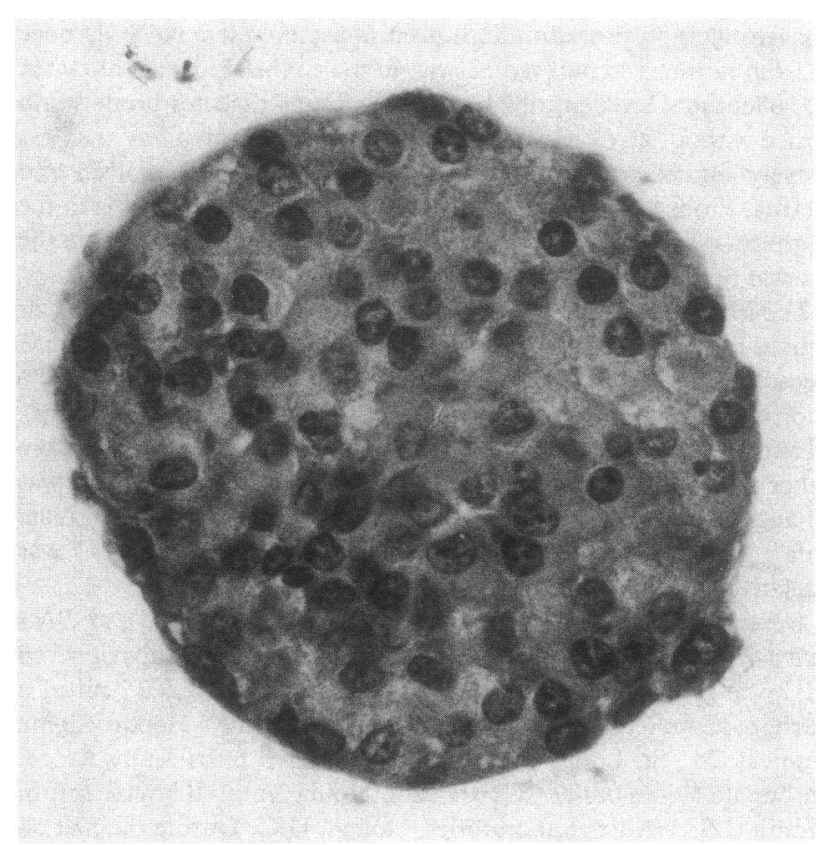

Figure 3. Female NOD mouse islet, 12 wk of age, cultured for 1 wk in medium RPMI $1640+10 \%$ calf serum (day 7). The islet is essentially devoid of mononuclear cells and shows in general a well-preserved structure. Hematoxylin and eosin. $\times 510$.

oldest animals had become glucose sensitive. To examine the effect of tissue culture on the glucose-stimulated insulin release, islets isolated from NMRI mice were also studied (Fig. 4). On day 0 these islets exhibited a prompt response to glucose, and this remained the same also on day 7 .

Addition of $5 \mathrm{mM}$ theophylline to the incubation medium containing $16.7 \mathrm{mM}$ glucose strongly augmented the insulin secretion on day 0 in all groups: (5-7 wk, 37.4 $\pm 7.1(n=12)$; 8-11 wk, 38.4 $\pm 5.2(n=13) ; 12-13 \mathrm{wk}, 28.0 \pm 6.4(n=6)$; NMRI, 80.1 $\pm 11.6(n=9) \mathrm{ng}$ insulin/10 islets $\times 60 \mathrm{~min})$. After culture there was an even higher insulin secretion, as compared with the same groups of islets examined on day 0 , in all groups of islets incubated in the presence of $16.7 \mathrm{mM}$ glucose $+5 \mathrm{mM}$ theophylline: $5-7 \mathrm{wk}, 120 \pm 11.3(n=12)(P<0.001)$; $8-11 \mathrm{wk}, 134 \pm 23.6(n=11)(P<0.001) ; 12-13 \mathrm{wk}, 119 \pm 25.9$ $(n=4)(P<0.01)$; NMRI, $124 \pm 16.9(n=9) \mathrm{ng}$ insulin/10 islets $\times 60 \mathrm{~min}(P<0.05)$.

Islet (pro)insulin and total protein biosynthesis. There was no difference in the rates of (pro)insulin biosynthesis at 1.7 $\mathrm{mM}$ glucose on day 0 between the different groups of NOD mice (Table III). At $16.7 \mathrm{mM}$ glucose the rate of (pro)insulin biosynthesis appeared lower in the islets of 12-13-wk-old mice; however, this difference did not attain statistical signifcance. The islets of the oldest mice exhibited an elevated total protein biosynthesis at the low glucose concentration. All groups of islets could increase both their (pro)insulin and total protein biosynthesis at the high glucose concentration. Furthermore, the (pro)insulin biosynthesis was preferentially stimulated by glucose. After culture all groups of islets showed higher rates of (pro)insulin biosynthesis as compared to day 0 . This probably reflects that the islets has been cultured at 11.1 $\mathrm{mM}$ glucose, which stimulates the (pro)insulin biosynthesis of the $\beta$-cells. On day 0 the contribution of the (pro)insulin frac- 
Table II. Insulin and DNA Contents of Pancreatic Islets from Female NOD Mice of Different Age, Immediately after Isolation (Day 0) and after $7 d$ of Culture (Day 7)

\begin{tabular}{|c|c|c|c|c|c|c|}
\hline \multirow[b]{2}{*}{ Age } & \multicolumn{2}{|c|}{ DNA content } & \multicolumn{2}{|c|}{ Insulin content } & \multicolumn{2}{|c|}{ Insulin content/DNA } \\
\hline & Day 0 & Day 7 & Day 0 & Day 7 & Day 0 & Day 7 \\
\hline$w k$ & \multicolumn{2}{|c|}{ ng $D N A / 10$ islets } & \multicolumn{2}{|c|}{ ng insulin/10 islets } & \multicolumn{2}{|c|}{ ng insulin/ng DNA } \\
\hline $5-7$ & $\begin{array}{c}170 \pm 20.4 \\
(16)\end{array}$ & $\begin{array}{l}160 \pm 14.1 \\
(15)\end{array}$ & $\begin{array}{c}433 \pm 38.9 \\
(16)\end{array}$ & $\begin{array}{c}407 \pm 36.3 \\
(16)\end{array}$ & $\begin{array}{c}2.8 \pm 0.2 \\
(16)\end{array}$ & $\begin{array}{c}2.8 \pm 0.3 \\
(15)\end{array}$ \\
\hline $8-11$ & $\begin{array}{c}282 \pm 37.5^{* *} \\
(12)\end{array}$ & $\begin{array}{c}179 \pm 27.1 \\
(13)\end{array}$ & $\begin{array}{c}535 \pm 59.7 \\
(14)\end{array}$ & $\begin{array}{c}357 \pm 37.3 \\
(14)\end{array}$ & $\begin{array}{l}2.1 \pm 0.2^{* *} \\
. \quad(12)\end{array}$ & $\begin{array}{c}2.4 \pm 0.3 \\
(13)\end{array}$ \\
\hline $12-13$ & $\begin{array}{c}381 \pm 53.0^{* * * *} \\
(9)\end{array}$ & $\begin{array}{c}209 \pm 36.0 \\
\text { (7) }\end{array}$ & $\begin{array}{c}604 \pm 54.8^{*} \\
(9)\end{array}$ & $\begin{array}{c}277 \pm 27.3^{*} \\
\text { (7) }\end{array}$ & $\begin{array}{c}1.8 \pm 0.4^{*} \\
(9)\end{array}$ & $\begin{array}{c}1.7 \pm 0.5^{*} \\
(7)\end{array}$ \\
\hline
\end{tabular}

The islets were isolated from nonstarved NOD mice at different age as given in the first column. The islet DNA and insulin content was determined both on the day of isolation (day 0 ) and after 1 wk of culture (day 7) in medium RPMI $1640+10 \%$ calf serum. Islet DNA content was measured fluorophotometrically in water homogenates of the islets and the insulin content was determined by RIA in acid ethanol extracts of the homogenized islets. Values are given as means \pm SEM for the number of animals given within parentheses. ${ }^{*},{ }^{* *}$, and ${ }^{* * *}$ denote $P<0.05$, $<0.01$ and $<0.001$, respectively, when compared on corresponding days to the 5-7-wk-old mice, using Student's unpaired $t$ test.

tion to the total protein biosynthesis in the islets of the 8-11wk-old mice was significantly lowered at $16.7 \mathrm{mM}$ glucose. After the culture period this persisted and also the islets of the oldest mice displayed a slight decrease compared with 5-7wk-old islets.

Islet glucose oxidation. In these experiments islets isolated from 12-13-wk-old NOD mice and from NMRI mice were studied (Table IV). The NOD islets showed a higher rate of glucose oxidation at $1.7 \mathrm{mM}$ glucose on day 0 compared with day 7. On day 0 the islets of the NOD mice increased their glucose oxidation rates 7.4 times at $16.7 \mathrm{mM}$ glucose. However, on day 7 they increased their glucose oxidation 21 times and this was not only due to a lower basal glucose oxidation, but also due to an increased glucose oxidation rate at $16.7 \mathrm{mM}$

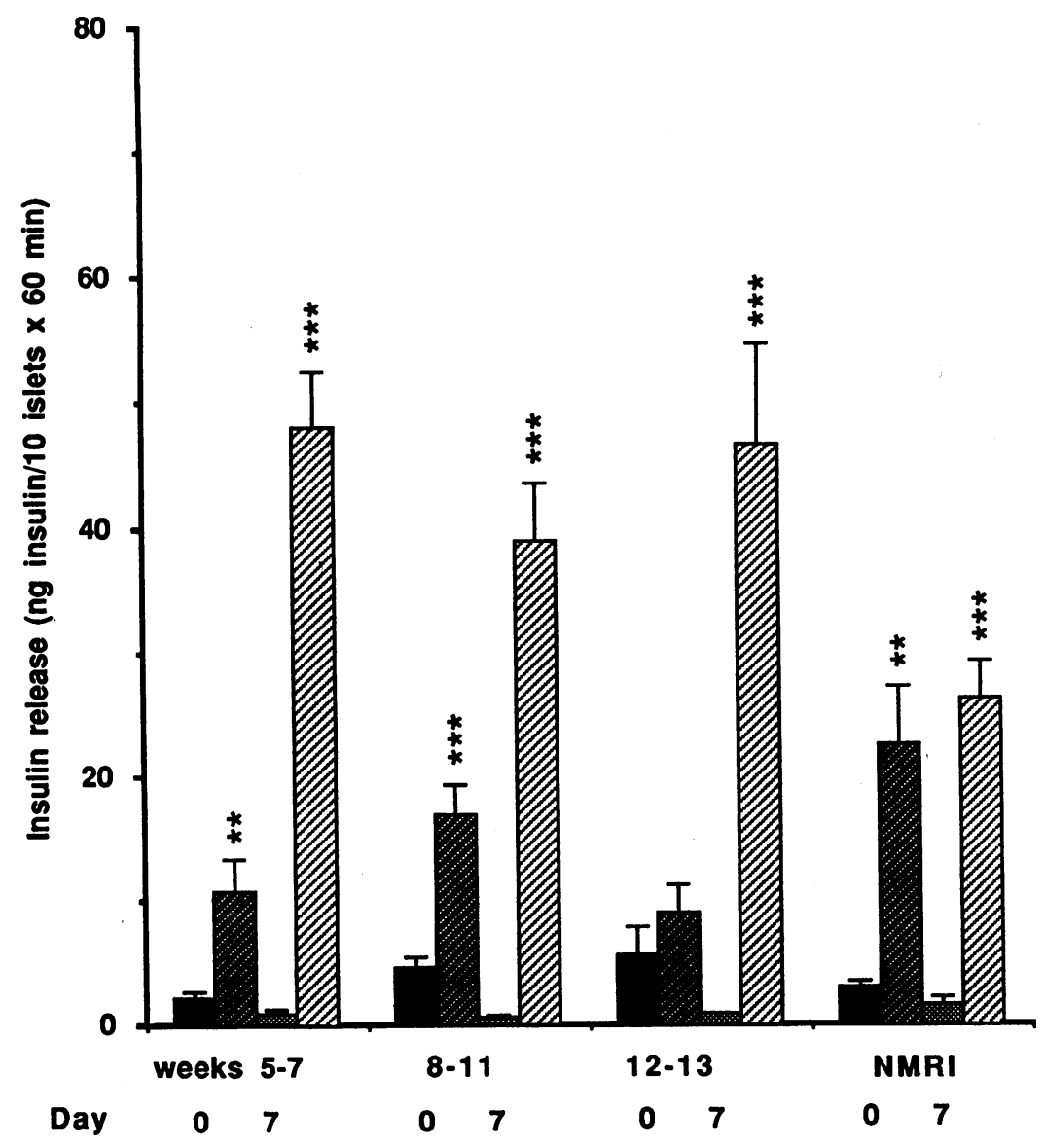

Figure 4. Insulin release from isolated pancreatic islets of female NOD mice at different ages and from male, 12-wk-old, NMRI mice. The islets were incubated in medium containing $1.67 \mathrm{mM}$ glucose, and after $60 \mathrm{~min}$ the medium was removed and the islets were incubated for another $60 \mathrm{~min}$ in medium containing $16.7 \mathrm{mM}$ glucose. The insulin release was examined immediately after isolation (day 0$)(1.67 \mathrm{mM}$ glucose, black bars; $16.7 \mathrm{mM}$ glucose, dark hatched bars) and after $1 \mathrm{wk}$ in culture (day 7) (1.67 mM glucose, stippled bars; $16.7 \mathrm{mM}$ glucose, light hatched bars). ${ }^{* *}$ and ${ }^{* * *}$ denote $P<0.01$ and $<0.001$ using Student's paired $t$ test comparing basal insulin release (1.67 mM glucose) with the insulin release at 16.7 mM glucose within each group on days 0 and 7 . 
Table III. Rates of (Pro)insulin and Total Protein Biosynthesis in Pancreatic Islets Isolated from NOD Mice of Different Ages, Immediately after Isolation (Day 0) and after $7 \mathrm{~d}$ of Culture (Day 7)

\begin{tabular}{|c|c|c|c|c|c|c|}
\hline \multirow[b]{4}{*}{ Age } & \multicolumn{2}{|c|}{ (Pro)insulin biosynthesis } & \multicolumn{2}{|c|}{ Total protein biosynthesis } & \multicolumn{2}{|c|}{$\begin{array}{l}\text { Fraction (pro)insulin } \\
\text { of total protein biosynthesis }\end{array}$} \\
\hline & \multicolumn{6}{|c|}{ Glucose } \\
\hline & \multicolumn{6}{|c|}{$m M$} \\
\hline & 1.7 & 16.7 & 1.7 & 16.7 & 1.7 & 16.7 \\
\hline$w k$ & \multicolumn{4}{|c|}{$d p m \times 10^{3} / 20$ islets $\times 2 h$} & \multicolumn{2}{|c|}{$\%$} \\
\hline \multicolumn{7}{|l|}{$5-7$} \\
\hline Day 0 & $11.4 \pm 1.8$ & $45.2 \pm 7.4$ & $65.4 \pm 4.8$ & $127 \pm 15$ & $17.1 \pm 1.7$ & $35.4 \pm 2.8$ \\
\hline Day 7 & $22.3 \pm 3.8$ & $60.4 \pm 11$ & $97.8 \pm 15$ & $124 \pm 17$ & $25.5 \pm 1.4$ & $46.5 \pm 4.1$ \\
\hline \multicolumn{7}{|l|}{$8-11$} \\
\hline Day 0 & $11.4 \pm 1.6$ & $43.5 \pm 7.3$ & $83.5 \pm 18$ & $173 \pm 38$ & $15.3 \pm 1.3$ & $28.4 \pm 1.9^{*}$ \\
\hline Day 7 & $21.3 \pm 3.2$ & $48.2 \pm 8.5$ & $87.3 \pm 14$ & $134 \pm 24$ & $23.2 \pm 1.2$ & $38.0 \pm 1.3^{*}$ \\
\hline \multicolumn{7}{|l|}{$12-13$} \\
\hline Day 0 & $13.6 \pm 3.5$ & $29.3 \pm 4.9$ & $118 \pm 21^{*}$ & $147 \pm 38$ & $13.2 \pm 2.2$ & $26.3 \pm 3.4$ \\
\hline Day 7 & $28.9 \pm 7.2$ & $55.7 \pm 5.8$ & $100 \pm 17$ & $158 \pm 22$ & $27.5 \pm 3.0$ & $37.2 \pm 1.7^{*}$ \\
\hline
\end{tabular}

The islets were isolated from nonstarved NOD mice at different age as given in the first column. The amount of labeled L-[4.5- $\left.{ }^{3} \mathrm{H}\right]$ leucine (pro)insulin was determined by an immunoabsorption technique and the total protein biosynthesis was measured in TCA precipitates of the islet homogenate. Values are means \pm SEM for $9-12$ experiments in each group. ${ }^{*}$ denotes $P<0.05$ for a chance difference vs. the 5-7-wk-old mice, compared on corresponding days after isolation using Student's unpaired $t$ test.

glucose. The islets of the NMRI mice showed similar glucose oxidation rates on day 0 and day 7 both at low and high glucose concentrations.

To assess a possible contribution of the infiltrating mononuclear cells to the islet glucose oxidation rate on day 0 , also the $\mathrm{D}-\left[\mathrm{U}-{ }^{14} \mathrm{C}\right] \mathrm{glucose}$ oxidation of splenic cells isolated from 12-13-wk-old NOD mice was measured. The glucose oxidation rates at $1.7 \mathrm{mM}$ glucose was $628 \pm 189 \mathrm{pmol} / 90 \mathrm{~min} \times 2$ $\times 10^{6}$ cells $(n=8)$, and at $16.7 \mathrm{mM}$ glucose it was $797 \pm 182$

Table IV. Rates of Glucose Oxidation in Pancreatic Islets Isolated from 12-13-wk-old NOD Mice and NMRI Mice Immediately after Isolation (Day 0) and after $1 \mathrm{wk}$ in Culture (Day 7)

\begin{tabular}{|c|c|c|c|c|c|c|}
\hline \multirow[b]{5}{*}{ Mice } & \multicolumn{6}{|c|}{ Islet glucose oxidation } \\
\hline & \multicolumn{3}{|c|}{ Day 0} & \multicolumn{3}{|c|}{ Day 7} \\
\hline & \multicolumn{2}{|c|}{ Glucose } & & \multicolumn{2}{|c|}{ Glucose } & \\
\hline & \multicolumn{2}{|c|}{$m M$} & & \multicolumn{2}{|c|}{$m M$} & \\
\hline & 1.7 & 16.7 & $\begin{array}{c}\text { Ratio } \\
(16.7 / 1.7)\end{array}$ & 1.7 & 16.7 & $\begin{array}{c}\text { Ratio } \\
(16.7 / 1.7)\end{array}$ \\
\hline & \multicolumn{6}{|c|}{ pmol glucose $/ 10$ islets $\times 90 \mathrm{~min}$} \\
\hline $\operatorname{NOD}(n=11)$ & $49 \pm 8$ & $304 \pm 37$ & $7.4 \pm 1.0$ & $27 \pm 4^{*}$ & $456 \pm 53^{* *}$ & $21 \pm 4.7^{*}$ \\
\hline $\operatorname{NMRI}(n=7)$ & $32 \pm 6$ & $389 \pm 30$ & $15 \pm 2.6$ & $27 \pm 5$ & $392 \pm 36$ & $17 \pm 2.8$ \\
\hline
\end{tabular}

The islets were isolated from nonstarved 12-13-wk-old female NOD and from male NMRI mice. The islet glucose oxidation was determined both on the day of isolation (day 0 ) and after 1 wk of culture (day 7) in medium RPMI 1640 $+10 \%$ calf serum. The islets were incubated in $\mathrm{KRBH}$ at either 1.7 or 16.7 $\mathrm{mM}$ glucose in the presence of $\mathrm{D}-\left[\mathrm{U}-{ }^{14} \mathrm{C}\right] \mathrm{glucose}$ for $90 \mathrm{~min}$ at $37^{\circ} \mathrm{C}\left(\mathrm{O}_{2} / \mathrm{CO}_{2}\right.$; 95:5). The ratio gives the relative increase in islet glucose oxidation when comparing the rates at 16.7 with $1.7 \mathrm{mM}$ glucose. Values are means $\pm S E M$ for $n$ animals. ${ }^{*}$ and ${ }^{* *}$ denote $P<0.05$ and $<0.01$, respectively, when comparing islets from the same animal on day 0 with day 7 , using Student's paired $t$ test. $\mathrm{pmol} / 90 \mathrm{~min} \times 2 \times 10^{6}$ cells $(n=12)$. If the decrease in the islet DNA content on day 7 compared with day 0 mainly reflects the loss of mononuclear cells, the number of infiltrating cells is roughly 29,000 per 10 islets, assuming a DNA content of $6 \mathrm{pg} / \mathrm{cell}$. If the glucose oxidation rates of the splenocytes are similar to that of the mononuclear cells in the islets, the contribution of these cells to the total islet glucose oxidation would be $\sim 9 \mathrm{pmol}$ at $1.7 \mathrm{mM}$ glucose $/ 90 \mathrm{~min} \times 10$ islets and 12 pmol at $16.7 \mathrm{mM}$ glucose $/ 90 \mathrm{~min} \times 10$ islets. These low glucose oxidation rates of the splenocytes are in agreement with previous reports (24).

\section{Discussion}

The goal of the present investigation was to characterize the $\beta$-cell function of islets isolated from animals spontaneously developing IDDM. Despite the lymphocytic infiltration, it was possible to isolate islets from NOD mice up to $13 \mathrm{wk}$ of age. After that age, the islet yield per pancreas was insufficient to allow experiments in which islets could be studied both before and after culture. This probably reflects the gradual reduction of $\beta$-cells owing to inflammatory islet lesions, which makes the collagenase islet isolation procedure unsuitable.

In line with the observations of a progressively disturbed intravenous glucose tolerance test in the older animals, the islets isolated from these mice exhibited the most marked suppression in $\beta$-cell function on day 0 . Conceivably the suppressive effect was inflicted to the $\beta$-cells in vivo and subsequently this state persisted acutely after isolation of the islets. It is likely that the failure of these islets to release insulin in response to glucose was related to a defect in their glucose metabolism, as evidenced by the present glucose oxidation data. Indeed, an intact oxidative metabolism is crucial for the stimulation of insulin secretion from the $\beta$-cells by nutrient secretagogues (25). These findings are also in agreement with previously re- 
ported data, suggesting that an impaired glucose metabolism in islet cells may develop after in vitro exposure to various types of toxic injuries (26). The impairment of glucose-stimulated insulin release was partly overcome by addition of theophylline. In line with this an enhanced insulin response to nonnutrient secretagogues, as compared with glucose, has also been observed after pancreas perfusions of NOD mice (27) and in "early" IDDM patients (28).

The elevated DNA content and total protein biosynthesis at $1.7 \mathrm{mM}$ glucose on day 0 of the islets isolated from the older mice, most probably reflect the contribution of infiltrating immune cells in the islets and in the periinsular area (cf. Fig. 1). An obvious possibility is that the immune cells in vivo induced the suppression of the islet glucose oxidation and glucose-stimulated insulin release observed in vitro. However, the mediator(s) of this putative suppression remains to be clarified. Humoral factors (29), cytotoxic T cells, natural killer cells, and macrophages (30-35) may exert such effects. Furthermore, pancreatic islet-specific $\mathrm{CD}^{+} \mathrm{T}$ cell clones isolated from spleens and lymph nodes (36) and $\mathrm{CD}^{+}$and $\mathrm{CD}^{+} \mathrm{T}$ cells from islets (37) of NOD mice, which may mediate islet destruction in vivo, have been isolated. It has also been postulated that a prolonged subclinical hyperglycemia can induce a condition of "glucose blindeness" in the $\beta$-cells (38). In addition cytokines, mainly interleukin 1 locally secreted by macrophages, may be toxic to the islet $\beta$-cells $(39,40)$. Despite that mouse pancreatic islet $\beta$-cells may be less sensitive to cytotoxicity induced by interleukin 1 (41), there is some resemblance between the presently studied NOD female mouse islets and rat pancreatic islets exposed for prolonged time in vitro to interleukin $1 \beta$. These islets show an elevated basal glucose oxidation and a blunted insulin response to glucose (42), which can partly be reversed by a phosphodiesterase inhibitor, i.e., theophylline (43) and 3-isobutyl-1-methylxanthine (44). On the other hand, the (pro)insulin biosynthesis of the islets isolated from the NOD mice was only moderately affected, whereas it was clearly decreased after interleukin $1 \beta$ treatment $(42,45)$. Nevertheless the impairment inflicted by interleukin 1 on the insulin secretion was more profound than that on the (pro)insulin biosynthesis (42). It is conceivable that islets in NOD mice at a later stage, i.e., closer to degeneration also will display a clearcut decrease in the biosynthesis of (pro)insulin.

The finding that the islets isolated from NMRI mice showed the same rates of insulin secretion on both days 0 and 7 argues against the possibility that the improved function of the islets from the NOD mice was solely an effect of tissue culture. The cultured NOD islets became depleted of the infiltrating mononuclear cells, probably because of a lack of stimulating mitogens such as interleukin 2 in the medium (46), and this coincided with a normalized islet DNA content, an increased glucose oxidation rate and an enhanced insulin release at high glucose. This implies that the invading cells, indeed, exerted an inhibitory action in vivo on the islet capacity to release insulin. In contrast, despite the depletion of the immune cells after culture the islet insulin content/DNA was still decreased in the 12-13-wk-old mice. This could indicate either that death and a net loss of irreversibly damaged $\beta$-cells from these islets have occured during the insulitis process, or that the number of $\beta$-cells per islet remained intact but their insulin content was reduced. The function of the glucagon producing cells of the islets was not evaluated in this study, but it has been reported that a hypersecretion of glucagon develops in diabetic NOD mice (47), and thus a role of this hormone in the presently observed glucose intolerance in the older mice can not be excluded.

A restoration of function in the surviving $\beta$-cells after culture following different noxious treatments has been observed after alloxan (48), heat-shock (49), and interleukin $1(43,44$, 50) exposure. However, after streptozotocin-induced injury, the inhibition of $\beta$-cell function persisted and even progressed in culture (51-53). The fact that the islets isolated from NOD mice, at an early stage of $\beta$-cell destruction, can revert their impaired $\beta$-cell function in vitro is encouraging. Extended to the in vivo situation, the present results could indicate that if the immunologically induced $\beta$-cell damage is arrested, there is a population of suppressed but still viable $\beta$-cells able to resume a normal function.

\section{Acknowledgments}

We thank Anna-Britta Andersson, Eva Forsbeck, Astrid Nordin, and Margareta Engkvist for excellent technical assistance.

This work was supported by grants from the Swedish Medical Research Council (12X-109; 12X-8273), the Swedish Diabetes Association, the Swedish Society of Medicine, the Nordic Insulin Fund, AageLouis Hansens Mindefond, the Juvenile Diabetes Fondation International, the Hoechst Diabetes Foundation, Amundsons Fond, Magnus Bergvalls Stiftelse, and the Torsten and Ragnar Söderbergs Foundation. Dr. Eizirik is the recipient of a postdoctoral fellowship from the Juvenile Diabetes Foundation International.

\section{References}

1. Eisenbarth, G. S., J. Connely, and J. S. Soeldner. 1987. The "natural" history of type I diabetes. Diabetes Metab. Rev. 3:873-891.

2. Tochino, Y. 1987. The NOD mouse as a model of type 1 diabetes. 1987. CRC Crit. Rev. Immunol. 8:49-81.

3. Kolb, H. 1987. Mouse models of insulin-dependent diabetes: low-dose streptozotocin-induced diabetes and nonobese diabetic (NOD) mice. Diabetes Metab. Rev. 3:751-778.

4. Leiter, E. H., M. Prochazka, and D. L. Coleman. 1987. Animal model of human disease: the non-obese diabetic (NOD) mouse. Am. J. Pathol. 128:380-383.

5. Fujita, T., R. Yui, Y. Kusumoto, Y. Serizawa, S. Makino, and Y. Tochino. 1982. Lymphocytic insulitis in a "non-obese diabetic (nod)" strain of mice: an immunohistochemical and electron microscope investigation. Biomed. Res. 3:429-443.

6. Signore, A., P. Pozzilli, E. A. M. Gale, D. Andreani, and P. C. L. Beverley. 1987. The natural history of lymphocyte subsets infiltrating the pancreas of NOD mice. Diabetologia. 32:282-289.

7. Prochazka, M., E. H. Leiter, D. V. Serreze, and D. L. Coleman. 1987. Three recessive loci required for insulin-dependent diabetes in nonobese diabetic mice. Science (Wash. DC). 237:286-289.

8. Wicker, L. S., B. J. Miller, L. Z. Coker, S. E. McNally, S. Scott, Y. Mullen, and M. C. Appel. Genetic control of diabetes and insulitis in the nonobese diabetic (NOD) mouse. 1987. J. Exp. Med. 165:1639-1654.

9. Wicker, L. S., B. J. Miller, P. A. Fischer, A. Pressey, and L. B. Peterson. 1989. Genetic control of diabetes and insulitis in nonobese diabetic mouse: pedigree analysis of a diabetic $\mathrm{H}-2^{\text {nod/b }}$ heterozygote. 1989. J. Immunol. 142:781-784.

10. Yamada, K., K. Novaka, T. Hanafusa, T. Miyazaki, H. Toyoshima, and S. Tarui. 1982. Prevention and therapeutic effects of largedose nicotinamide injections on diabetes associated with insulitis: an observation in nonobese diabetic mice. Diabetes. 31:749-753.

11. Nomikos, I. N., S. J. Prowse, P. Carotenuto, and K. J. Lafferty. 
1986. Combined treatment with nicotinamide and desferrioxamine prevents islet allograft destruction in NOD mice. Diabetes. 35:13021304.

12. Formby, B., N. Miller, R. Garret, and C. M. Peterson. 1987. Effects of low-dose cyclosporine prophylaxis in nonobese diabetic mice. J. Pharmacol. Exp. Ther. 241:1106-1111.

13. Klandorf, H., A. R. Chirra, A. DeGruccio, and D. J. Girman. 1989. Dimethyl sulfoxide modulation of diabetes onset in NOD mice. Diabetes. 38:194-197.

14. Sandler, S., and A. Andersson. 1985. Modulation of streptozotocin-induced insulitis and hyperglycaemia in the mouse. Acta Pathol. Microbiol. Immunol. Scand. Sect. A Pathol. 93:93-98.

15. Jansson, L., and S. Sandler. 1988. The influence of cyclosporin $A$ on the vascular permeability of the pancreatic islets and on diabetes induced by low doses of streptozotocin in the mouse. Virchows Arch. A Pathol. Anat. 412:225-230.

16. Howell, S. L., and K. W. Taylor. 1968. Potassium ions and the secretion of insulin by islets of Langerhans incubated in vitro. Biochem. J. 108:17-24.

17. Keen, H., J. B. Field, and I. H. Pastan. 1963. A simple method for in vitro metabolic studies using small volumes of tissue and medium. Metab. Clin. Exp. 12:143-174.

18. Krebs, H. A., and K. Henseleit. 1932. Untersuchungen über die Harnstoffbildung im Tierkörper. Hoppe-Seylers Z. Physiol. Chem. 210:33-66.

19. Heding, L. G. 1972. Determination of total serum insulin (IRI) in insulin-treated patients. Diabetologia. 8:260-266.

20. Kissane, J. M., and E. Robins. The fluorometric measurement of deoxyribonucleic acid in animal tissues with special reference to the central nervous system. 1958. J. Biol. Chem. 233:184-188.

21. Hinegardner, R. T. 1971. An improved fluorometric assay for DNA. Anal. Biochem. 39:197-201.

22. Halban, P. A., C. B. Wollheim, B. Blondel, and A. E. Renold. 1980. Long-term exposure of isolated pancreatic islets to mannoheptulose: evidence for insulin degradation in the $\beta$-cell. Biochem. Pharmacol. 29:2625-2633.

23. Andersson, A., and S. Sandler. 1983. Viability tests of cryopreserved endocrine pancreatic cells. Cryobiology. 20:161-168.

24. Newsholme, E. A., B. Crabtree, and M. S. M. Ardawi. 1985. The role of high rates of glycolysis and glutamine utilization in rapidly dividing cells. Biosci. Rep. 5:393-400.

25. Malaisse, W. J. 1983. Insulin release: the fuel hypothesis. Diab. Metab. 9:313-320.

26. Eizirik, D. L., and S. Sandler. 1989. Function and metabolism of pancreatic $\beta$-cells maintained in culture following experimentally induced damage. Pharmacol. Toxicol. 65:163-168.

27. Kano, Y., T. Kanatsuna, N. Nakamura, Y. Kitagawa, H. Mori, S. Kajiyama, K. Nakano, and M. Kondo. 1986. Defect of the firstphase insulin secretion to glucose stimulation in the perfused pancreas of the nonobese diabetic (NOD) mouse. Diabetes. 35:486-490.

28. Ganda, O. P., S. Srikanta, S. J. Brink, M. A. Morris, R. E. Gleason, J. S. Soeldner, and G. S. Eisenbarth. 1984. Differential sensitivity to $\beta$-cell secretagogues in "early", type 1 diabetes mellitus. Diabetes. 33:516-521.

29. Kanatsuna, T., S. Baekkeskov, Å. Lernmark, and J. Ludvigsson. 1983. Immunoglobulin from insulin-dependent diabetic children inhibits glucose-induced insulin release. Diabetes. 32:520-523.

30. McEvoy, R. C., J. Andersson, S. Sandler, and C. Hellerström. 1984. Multiple, low-dose streptozotocin-induced diabetes in the mouse: evidence for stimulation of a cytotoxic, cellular immune response against an insulin-producing beta cell line. J. Clin. Invest. 74:715-722.

31. MacKay, P., A. Boulton, and A. Rabinovitch. 1985. Lymphoid cells of BB/W diabetic rats are cytotoxic to islet B-cells in vitro. Diabetes. 34:706-709.

32. MacKay, P., J. Jacobson, and A. Rabinovitch. 1986. Spontaneous diabetes mellitus in the Bio-Breeding/Worcester rat: evidence in vitro for natural killer cell lysis of islet cells. J. Clin. Invest. 77:916-924.
33. Schwizer, R. W., E. H. Leiter, and R. Evans. 1984. Macrophage-mediated cytotoxicity against cultured pancreatic islet cells. Transplantation (Baltimore). 37:539-544.

34. Appels, B., V. Burkart, G. Kantwerk-Funke, J. Funda, V. Kolb-Bachofen, and H. Kolb. 1989. Spontaneous cytotoxicity of macrophages against pancreatic islet cells. J. Immunol. 142:3803-3808.

35. Nagy, M. W., E. K. Chan, M. Teruya, L. E. Forrest, V. Likhite, and M. A. Charles. 1989. Macrophage-mediated islet cell cytotoxicity in BB rats. Diabetes. 38:1329-1331.

36. Haskins, K., M. Portas, B. Bergman, K. Lafferty, and B. Bradley. 1989. Pancreatic islet-specific T-cell clones from nonobese diabetic mice. Proc. Natl. Acad. Sci. USA. 86:8000-8004.

37. Reich, E.-P., R. S. Sherwin, O. Kanagawa, and C. A. Janeway, Jr. 1989. An explanation for the protective effect of the MHC class II I-E molecule in murine diabetes. Nature (Lond.). 341:326-328.

38. Weir, G. C., J. L. Leahy, and S. Bonner-Weir. 1986. Experimental reduction of B-cell mass: implications for the pathogenesis of diabetes. 1986. Diabetes Metab. Rev. 2:125-161.

39. Nerup, J., T. Mandrup-Poulsen, and J. Mölvig. 1987. The HLA-IDDM association: implications for etiology and pathogenesis of IDDM. Diabetes Metab. Rev. 3:779-802.

40. Bendtzen, K. 1989. Immune hormones (cytokines): pathogenic role in autoimmune rheumatic and endocrine diseases. Autoimmunity. 2:177-189.

41. Leiter, E. H. 1987. Murine macrophages and pancreatic $\beta$ cells: chemotactic properties of insulin and $\beta$-cytostatic action of interleukin 1. J. Exp. Med. 166:1174-1179.

42. Sandler, S., A. Andersson, and C. Hellerström. 1987. Inhibitory effects of interleukin 1 on insulin secretion, insulin biosynthesis and oxidative metabolism of isolated rat pancreatic islets. Endocrinology. 121:1424-1431.

43. Eizirik, D. L., E. Strandell, K. Bendtzen, and S. Sandler. 1988. Functional characteristics of rat pancreatic islets maintained in culture following exposure to human interleukin 1. Diabetes. 37:916-919.

44. Rabinovitch, A., C. Pukel, and H. Baquerizo. 1988. Interleukin-1 inhibits glucose-modulated insulin and glucagon secretion in rat islet monolayer cultures. Endocrinology. 122:2393-2398.

45. Spinas, G. A., B. S. Hansen, S. Linde, W. Kastern, J. Mölvig, T. Mandrup-Poulsen, C. A. Dinarello, J. H. Nielsen, and J. Nerup. 1987. Interleukin 1 dose-dependently affects the biosynthesis of (pro)insulin in isolated rat islets of Langerhans. Diabetologia. 30:474-480.

46. Gillis, S., and J. Watson. 1981. Interleukin-2 dependent culture of cytolytic T cell lines. Immunol. Rev. 54:81-109.

47. Ohneda, A., T. Kobayashi, J. Nihei, Y. Tochino, H. Kanaya, and S. Makino. 1984. Insulin and glucagon in spontaneously diabetic non-obese mice. Diabetologia. 27:460-463.

48. Eizirik, D. L., and S. Sandler. 1988. Functional restoration of cultured mouse pancreatic islets after in vitro exposure to alloxan. Pharmacol. Toxicol. 63:396-399.

49. Welsh, M., D. L. Eizirik, and E. Strandell. 1988. Heat-shock treatment of mouse pancreatic islets results in a partial loss of islet cells but no remaining functional impairment among the surviving $\beta$ cells. J. Mol. Endocrinol. 1:27-31.

50. Comens, P. G., B. A. Wolf, E. R. Unanue, P. E. Lacy, and M. L. McDaniel. 1987. Interleukin 1 is potent modulator of insulin secretion from isolated rat islets of Langerhans. Diabetes. 36:963-970.

51. Bolaffi, J. L., R. E. Nowlain, L. Cruz, and G. M. Grodsky. 1986. Progressive damage of cultured pancreatic islets after single early exposure to streptozotocin. Diabetes. 35:1027-1033.

52. Strandell, E., D. L. Eizirik, O. Korsgren, and S. Sandler. 1988. Functional characteristics of cultured mouse pancreatic islets following exposure to different streptozotocin concentrations. Mol. Cell. Endocrinol. 59:83-91.

53. Zucker, P. F., and M. C. Archer. 1988. Streptozotocin toxicity to cultured pancreatic islets of the syrian hamster. Cell. Biol. Toxicol. 4:349-356. 